\title{
EVALUATION OF BREWERS DRIED YEAST PROTEIN IN BROILER DIET
}

\author{
M.C. NIIKE*, A.S. AHMED and E.S. HARUNA \\ National Veterinary Research Institute, Vom, Nigeria. \\ (Receive1 4 Jan. 1985, Accepted 10 May 1985).
}

\begin{abstract}
The value of brewers dried yeast protein (BDY) as a replacement of fishmeal in the diet for broiler starters was investigated. In the experiment BDY replaced $0,25,50,75$ amd $100 \%$ of the fishmeal ir. the fiet. The average liveweight gain response to increasing levels of BDY at 6 weeks of age was $950.3 \mathrm{~g}, 980.7 \mathrm{~g}, 981.8 \mathrm{~g}, 950.5 \mathrm{~g}$ and $953.2 \mathrm{~g}$ respectively. While the figures for the feed/gain ratio were $2.35,2.28,2.30,32.36$ and 2.39 respectively. There was no significant differences between these values.

Also, the mean feed consumption data for different dietary treatment through the period showed no significant differences. This result suggests that under the conditions of this experiment BDY could :eplace completely all the fishmeal in the broiler starter diet without any adverse effect on the rate of gain, feed efficiency, or feed consumption of broiler chicks.
\end{abstract}

Key words: Brewers Yeast Protein Evaluation, Broilers

\section{INTRODUCTION}

The world shortage of protein particularly in developing countries like Nigeria has necessitated investigation of several novel sources of protein. Research on single-cell protein has shown that various species of yeast, bacteria and microfungi, contain high soncentration of protein which can be used in livestock feed (Mateles and Tannenbaum, 1968). Recent studies by Abbey, (1981) showed that protein, a single-cell protein, contains $72 \%$ crude protein and has metabolizable energy value of $14.0 \mathrm{MJ} / \mathrm{kg}$ which is higher than the figures quoted for herring fishmeal $13.35 \mathrm{MJ} / \mathrm{kg}$ and dehulled soya bean meal $10,59 \mathrm{MJ} / \mathrm{kg}$.

The study of yeast in its original form for poultry feeds has been rather limited. Evans (1968) studied the short term effects of yeast cells grown on hydrocarbon substrates to determine the liveweight gain and egg production. Lee and Yang (1966) evaluated yeast produced from petroleum by chick assay. Most of these earlier works were performed at laboratory level and in semi-synthetic environments, and casein and fishmeal were used as reference protein sources in semisynthetic feed formulations. The number of broilers tested were severely limited, some only four birds per treatment. The results derived from such trials are therefore of limited practical value.

Extensive short and long term experiments with chickens, have been carried out in U.S. and Britain concerning nutritional value of yeast grown on petroleum hydrocarbons (Stracklady; $1969,1970,1972,1973,1975)$. The results indicate the yeast cells when incorporated into diets at the expense of other major protein sources such as fishmeal and soya bean meal gave virtually identical results in terms of body weight, feed efficiency and egg production. There were no apparent changes in organoleptic characteristics of products obtained from chickens whose feed contained the yeasts.

Present Address: Department of Animal Production, University of Jos, Makurdi Campus, Makurdi, Nigeria. 
It would appear from the results of Daghir and Abdul-Baki, (1977) that there is need for supplementation of methionine and lysine for optimal performance when yeast protein produced from molasses is fed to chicks. With torullar yeast, Ringrose, (1949) showed that this protein can be used in growing chicken diets if supplemented with soya bean meal, chicks performing better in pelleted diets than in the mash form. Gilter, et al., (1958) concluded that the nutritive value of Torullar yeast fed in pelleted diet supplemented with methionine and ariginine was as good as that of soya bean meal.

Information on effects of replacing fishmeal with brewery yeast in commercial poultry feeds is very scanty. Brewery yeast, a fermentation by-product, causes extensive water pollution in this country. Treatment of this waste to obtain utilizable yeast as a source of feed protein should be useful in decreasing the shortage of protein-rich feed ingredients, the cost of poultry feeds and the problem of waste disposal. This idea is supported by a recent work by Vananuvat and Chiraratananon (1977) who showed that unprocessed brewers yeast could replace $25 \%$ of fishmeal or $24 \%$ of soya bean meal in a broiler starter ration without any adverse effect on feed efficiency. It seemed expedient therefore to evaluate brewery dried yeast for different classes of poultry feeds.

The purpose of this investigation was to study the effect of varying levels of brewers dried yeast protein on the body weight, liveweight gain, feed consumption and feed efficiency of broiler chicks.

\section{MATERIALS AND METHODS}

The experiment was conducted with one thousand Ross White broilers purchased from a local hatchery. The baby chicks were randomly divided into five equal four subgroups representing four replicates. The five groups were fed each of the five diets formulated to contain 0 , $25,50,75$ and $100 \%$ of brewers dried yeast. The yeast was substituted at the expense of fishmeal. The composition of the diets is shown in Table 1 . There were therefore five treatment groups replicated four times. The birds were reared on a cement floor covered with wood shavings. Heat was supplied during the first four weeks while water and feed were provided ad libitum.

The chicks were weighed at weekly intervals while feed consumption was determined daily. A record of mortality rate was kept. At the end of the experiment the data collected were subjected to analysis of variance as outlined by Steel and Torrie (1960) followed by determination of statistical significance of mean differences using Duncan's Multiple Range Test (Duncan, 1955).

\section{RESULTS}

Table 2 shows the cumulative body weight, feed consumption, liveweight gain, and feed efficiency (feed/gain ratio) of the chicks on different dietary treatments at 6 weeks of age. The data indicate that different proportions of the dried yeast incorporated into the diets did not affect the chick appetite. The data on average weekly liveweight gains were slightly inconsistent. However, rations containing the brewers dried yeast supported better growth rate and for the first four weeks were significantly higher than those on rations without the yeast. The growth rates of birds on diets with different levels of the yeast were good and are consistent with figures expected from this strain birds. The data on feed efficiency (feed/gain ratio) (Table 2) are again inconsistent but the results showed that the rations containing different pro- 
TABLE 1

Composition of rations $(\%)$

\begin{tabular}{|c|c|c|c|c|c|c|c|c|}
\hline Maize .. & . & $\ldots$ & . & $\ldots 54.75$ & 54.02 & 52.79 & 51.37 & 46.91 \\
\hline Groundnut Cak & e. . & $\ldots$ & . & . 31.0 & 31.0 & 31.50 & 31.5 & 33.0 \\
\hline Fishmeal $^{1}$ & $\ldots$ & $\ldots$ & . & $\ldots$ & 4.375 & 3.75 & 2.5 & - \\
\hline Brewers Dried Y & east ${ }^{2}$ & $\ldots$ & . & 一 & 1.355 & 2.71 & 5.42 & 10.84 \\
\hline Bone Meal . & . & . & . & . 3.0 & 3.0 & 3.0 & 3.0 & 3.0 \\
\hline Oyster shell .. & . & .. & . & . 0.5 & 0.5 & 0.5 & 0.5 & 0.5 \\
\hline Premix* & . & . & . & 0.25 & 0.25 & 0.25 & 0.25 & 0.25 \\
\hline Wheat Offal. . & . & $\cdots$ & $\cdots$ & 5.0 & 5.0 & 5.0 & 5.0 & 5.0 \\
\hline$\ldots \quad \ldots$ & $\ldots$ & 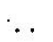 & . & $\ldots \quad 0.25$ & 0.25 & 0.25 & 0.25 & 0.25 \\
\hline Methionine .. & . & . & . & . 0.25 & 0.25 & 0.25 & 0.25 & 0.25 \\
\hline \multicolumn{3}{|c|}{ Protein (\%) (Calculated) } & . & . 24.2 & 23.9 & 24.1 & 24.1 & 23.96 \\
\hline \multicolumn{3}{|c|}{ Protein (\%) (Analysed) } & . & $\ldots 23.81$ & 23.76 & 24.2 & 23.9 & 23.86 \\
\hline
\end{tabular}

*Premix is a vitamin/mineral mixture cotaining all the vitamins, trace minerals and antibiotics required for optimum performance of broiler ducks.

1. Proximate chemical composition of fishmeal are as follows: Moisture $10.0 \%$; Crude protein, $65.7 \%$, Crude fibre, $0.45 \%$, Ash, 13.96\%, Fat, $10.9 \%$.

2. Proximate chemical composition of brewer's dried yeast are: Moisture, $6.3 \%$; Crude protein, 30.4\%; Crude fibre $0.1 \%$; Fat, 0.52 ; Ast, $4.4 \%$.

Vitamin (Dry basis) (Microgram:i/g) Thiamine, 74; Riboflavin 39; Nicotinic acid 3.0; Calcium pantothenate, 19; Biotin, 3; Folic acid 19; Pyrodoxine Hcl, 43.

\section{TABLE 2}

Effect of feeding different levels of brewers dried yeast on mean body weight, liveweight gain, feed consumption and feed/gain ratios on broiler starters at 6 weeks of age

\begin{tabular}{|c|c|c|c|c|c|}
\hline \multirow[t]{2}{*}{ Parameters } & \multicolumn{5}{|c|}{ Dietary (\%) } \\
\hline & $\theta$ & 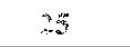 & $5 \hat{k}$ & 75 & $\sin$ \\
\hline arapeighr & $986,5 a$ & $M: 5 . \sim^{a}$ & 150.9 & $9 \times 7.52$ & 290.5 \\
\hline Un she Gain & $950.3 \mathrm{a}$ & 380.72 & $981.8 \%$ & 92053 & $36 \div 12$ \\
\hline स- Womsumblom & $23376^{2}$ & 393729 & $2 y-2$ & 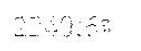 & $2 x^{2}+3$ \\
\hline Techan Railo & 2.350 & $\therefore 200$ & 2.302 & 2.563 & 280 \\
\hline
\end{tabular}


portions of brewers dried yeast were more efficiently utilised by the birds than those without the yeast. It would appear from these sesults that dietary treatments have no effect on the chick performance.

\section{DISCUSSION}

Brewers dried yeast contains low level of methionine (Block and Bolling, 1945; Chiao and Peterson, 1953 and Vananuvat and Kinsella, 1975b) hence all the diets used in this experiment were fortified with $0.25 \%$ feed grade methionine. There were no significant differences in growth rate, feed intake and feed efficiency (feed/gain ratio) between the birds receiving graded levels of brewers dried yeast and those on control diet. Similar results have been obtained by Vananuvat and Chiraratananon (1977), Gow et al., (1975) and Evans (1968). Gow et al., (1975) studied the use of bacterial protein replacing soya bean meal at $100 \%$ and fishmeal at 40 and $80 \%$ in broiler diets. They found no significant differences in liveweight or feed intake of any of the group after a 56- day feeding period. While Evans (1968) found that weight of broilers fed over 5- and 16week periods with control meals and meals ' containing hydrocarbon yeast replaced fishmeal at 75 and $100 \%$ levels showed no difference. The feed conversion ratio was also similar. However, our results differ from those of Hudsky et al (1980). These authors fed chicks, hens, broilers and ducks with yeast from ethanol and sulphite extracts. They found that only $5 \%$ of fishmeal can be replaced by yeast in diet for chicks and hens, $6 \%$ for broilers and 5\% for ducks. Similarly, Shacklady (1970) and Van Weerden and Shacklady (1970) concluded from their feeding trials with n-alkane grown yeast that satisfactory results were obtained with broilers when $10 \%$ yeast was used in replacing its equivalent in fish and soya bean meals. Above this level (15 and $20 \%$ ), they found that the response was somewhat variable. These results would appear to indicate that nutritional trials have to be carried out to establish replacement value of every type of yeast originating from whatever source. Information from one type of yeast should therefore not be extrapolated to cover yeasts from other sources.

It is interesting to note from the data presented here that the performance of birds on diets containing yeasts up to the highest substitution level, is identical with those on control diet in spite of the variations in dietary constituents. It was expected that Diet 1, the control diet, with $5 \%$ fishmeal should present the best amino acid profile followed by diets 2,3 , 4 and 5 in that order. Since our analysis of the yeast used in this experiment is not exhaustive, it is not out of realm of reason to speculate other mediating mechanisms as suggested by Mordenti (1980), that the addition of the yeast might (1) increase the diet palatability (2) though in chicken the interference of intestinal microflora is only slightly felt (Piva and Amerio, 1979) because of the rapid food passage in the digestive tract, we cannot ignore the possibility that a higher level of free vitamins particularly B group, may favour the development of useful microorganisms to the disadvantage of potentially harmful ones, maybe through $\mathrm{pH}$ modifications (Mordenti, 1980).

In conclusion, the results of the present experiment clearly show that brewery dried yeast can replace all the fishmeal protein in broiler starter diet. It is therefore expected that the use of brewery dried yeast in poultry feeds would help lower feed costs. At present time, Nigeria imports fishmeal to provide chicken feed protein supplements. Hence, government restrictions on hard currency expenditures could lead to extremely sound economic 
motives for utilizing brewery yeast in poultry feed. The authors have no doubt in their minds that the country's beer industries could produce enough brewers dried yeast for the country's needs if only there is a law forcing them to process brewery yeast. At the moment it is being wasted.

\section{REFERENCES}

ABBEY, B.W. 1981. Determination of the metabolizable energy contents of various samples of experimental protein pruteen. Abstract of papers "From Food deficiency to food sufficiency in the 80s" Rivers State University of Science and Technology Port Harcourt.

Block, R.J. and Bolling, D. 1945. The amino acids yielded by various yeasts after hydrolysis of the fat-free material - A comparative investigation. Arch. Biochem Biophys. 7; 313.

Chiao, J.S. and Petersen, W.H. 1953. Yeasts, methionine and cystine contents. J. Agric. Food Chem. 1; 1005 .

DAGHIR and ABDUL-BAKi, T.K. 1977. Yeast protein in broiler rations. Poult. Sci. 16; 1836-1841.

DUNCAN, D.B. 1955. Multiple range and Multiple F tests. Biometrics, 11; $1-42$.

Evans, G.H. 1968. Industrial production of singlecell protein from hydrocarbons. Single-cell Protein. Eds. R.T. Mateles and S.R. Tannenbaum. The M.I.T. Press Cambridge Mass. p. 243.

Gllter C., Finlayson, J.S., Banmann C.A., and M.L. SUNDE. 1958. Apparent bilogical value of pelleted and autoclaved torula yeast measured in various ways. Poutt. Sci. 37; 1314-1320.

Gow, J.S. LitTlehacles, J.D. SMith, S.R.L. and WALTER, R.B. 1975. SCP production from methanol: Bacteria. Single-cell Protein 11. Eds. S.R. Tannenbaum and D.I.C Wang. The M.I.T. Press, Cambridge, Mass p. 370.

Hudsky, Z., Machalek. E., Bartosova, J. and Satava. M. 1980. Effect of yeast from ethanol and sulphate extracts in the fowl nutrition. 6th European Poultry Conference Proceedings Vol. III Hamburg 8-12th September, 1980 p. 447.
LEE. P.K. and YANG, Y.E. 1966. Petroleum protein as supplement for chicks and rats. Taiwan Livestock Research Institute.

Mateles, R.T. and Tannenbaum, S.R. 1968. Eds. Single-cell protein. The M.T. Press Cambridge, Mass.

MORDENTI, A. 1980. Meeting on "Impiego dei proteolisati nella alimentazione degli animali in productione sootecniche" Verona February 281980.

Piva, C. and Americo, M. 1979. Meeting on "Agiornamenti di nutrizione avicola - Milan Dic 13, 1979.

RINGROSE, R.C. 1949. Nutritive properties of torula yeast for poultry. Poult, Sci. 28; $75-83$.

Shacklady, C.A. 1969. The use of hydrocarbongrown yeasts in Commercial type rations for pigs and poultry, 2nd International Conference Global Impact Appl. Microbiol. 1st Biotechnology and Bioengineering Symposium. Inter-Science 1; 77.

Shacklady, C.A. 1970. Safety in use and nutritional value of microbial protein. 3rd International Congress Food Science and Technology, Washington D.C. p. 743.

SHACKLADY, C.A. 1972. Yeast grown on hydrocarbon as new sources of protein. World Rev. Nutr. and Dietetics 14; 154.

SHaCkLADY, C.A. 1973. Value of SCP for animals. Single-cell Proteins 11. Eds. S.R. Tannenbaum and D.I.C. Wang. The M.T. Press Cambridge, Mass p. 489.

STEEL, R.G.D. and TorRIE, H.H. 1960. Ruinciples and procedures of statistics. McGraw-Hill Book Co., Inc. London.

Vananuvat, P. and Kinsella. J.E. 1975b. Production of yeast protein from crude lactose by Saccharomyces fragillies J. Agr. Food Chem. 23; 595.

Vananuvat, P. and Chiraratananon, R. 1977. The use of brewery yeast in commercial type ration for poultry. Wld. Poult. Sci. J. 33(2); 88.

VAN WEerden, F, and SHacklady, C.A. 1970. Hydrocarbon grown yeast in rations for chicks. Brit. Poult. Sci. 11; 189. 